\title{
Imperative for the Availability of Resources for Managing Secondary Functional Education in Rivers State, Nigeria
}

\begin{abstract}
Osaat, Dinah Sunday
*Corresponding Author: Osaat, Dinah Sunday Faculty of Education, Univeristy of Pothacourt

Abstract: The study investigated the imperative for the availability of resources for managing functional secondary education in Rivers state, Nigeria. Two research questions guided the study. The study adopted a descriptive survey design and the population comprised all the 247 secondary schools with a total of 247 principals and 247 vice principals who served as the respondents. Stratified random sampling technique was used to draw 128 principals and vice principals as the sample size which is $25 \%$ of the total respondents. Questionnaire tagged "Availability of Resources for Managing Functional Secondary Education Questionnaire” (ARMAFEQ) was the instrument used for data collection developed by the researcher. The instrument comprised two sections A\& B. Section A comprised demographic data while section B comprised the questionnaire items based on the variables of the study and was based on four points likert type scale of SA (4 points), A (3 points), D (2 points) and SD (1 point). Mean and standard deviation were the statistical instruments used for data analysis. The findings revealed that resources enhance functional basic education in the following ways; promotes understanding of subject matter, makes teaching and learning clearer, improves skills and knowledge among students, improves quality of teaching, improves teachers effectiveness etc. It also revealed that the level of availability of resources in schools for achieving managing functional secondary education in Rivers state, Nigeria generally is low. It was concluded that achieving a functional education in the face of poor availability of resources is a mirage and therefore recommended among others that the government should adequately fund the educational sectorand parents and community leaders should be involved in the provision of material resources in schools through donations and contributions.
\end{abstract}

\section{INTRODUCTION}

For any educational system to develop and empower its citizenry for survival such system has to be functional. FRN (2013) rightly stipulates the need for a functional education that would be relevant, practical to the recipient. Okeke in Osaat (2011) sees functional educational system as a process of learning itself which aids in the provision of skills, preparation of youths for economic social and political functions. Ojokheta, K. O. \& Omoregie, C. O. (2008) define functional education as a cumulative process of development of intellectual abilities, skills and attitudes and all of which form our various outlooks and dispositions to action in life.

A functional education is that which is practical and useful for its citizenry. Achieving functionality of education in secondary schools is a task that cannot be compromised. When education at the secondary level is not made functional, there will be that ripple effects on the recipient as he goes to the higher level of education.

Secondary education is the education that prepares and arms the recipients with the necessary abilities needed for next educational level or trade after primary school. Depending on various countries, secondary education may be called, high school, middle schools, gymnasia, lyceums, sixth-form colleges, vocational schools or preparatory schools. The use of each of the concepts depends on the desire of the immediate environment (Wikipedia in Igbudu \& Ipalibo-wokoma, 2017).

However, in Nigeria secondary education is that education students receive after primary education and before tertiary education with a broad goal of preparing the individual for useful living and higher education (FRN, 2013). From the goals of secondary education it is observed that secondary education is meant to be functional and set for the totality of the development of the child to fit into the society towards his well being and that of the society at large. 
One of the factors for managing a functional secondary education is to be in a conducive, lively and happy environment where the child will act enthusiastically (Osaat, 2011). The child should be seen in an environment where he can enquire and to know, to observe and to work and especially to play in a free atmosphere and in a suitable living condition. Therefore managing a functional secondary education demands the availability of resources in schools. Material resources in education otherwise known as educational facilities are materials which help to facilitate teaching and learning processes. Obodo in Amadioha (2013) posits that educational facilities are those things which enable a skillful teacher to achieve a level of instructional effectiveness that far exceeds what is possible when they are provided.

The need for availability of functional resources for a functional education cannot be over emphasized. Okeke (2007) posits that quality education to a large extent relies on the scale of facilities in a school. The level of friendliness of the school to the children in terms of availability of resources and play ground has been observed to be strong factor in achieving a functional education.

The need for a functional education for achieving economic and social sustainable development cannot be overemphasized. When there is functional education these three areas of development will be sustained to a large extent. According to Osaat (2011), a country that has a level of education, that is characterized with making people functional (self-employed), will yield increase GDP of a nation. Socially a country gotten from a functional education educational system rises above ignorance and superstitious to the level of self actualization, discipline orderliness etc. politically a developed country that is born of a functional education is built on a sound citizenship and ideology that is devoid of rancor and acrimony, lack of tribal sentiment in choice of political leaders, emphasis on citizen education, accountability and transparency in various offices and positions. All these can be achieved if there is proper management of this secondary level of education especially by the level of availability of resources to make the educational system functional. It has been observed that the graduates of secondary schools today cannot be useful to themselves and to the society while those who find in themselves in higher institutions still come out being useful also. The researcher is of the assumption that this level of education has not been given the desired serious look by proper management in terms of provision of material resources to make everything about school environment and teaching and learning particularly practical and functional.

Against this backdrop has the researcher intended to investigate into the imperative for availability of material resources and the levels of its availability in schools to achieve a functional secondary education in Rivers state, Nigeria.

\section{Statement Of Problem}

Making education functional should be a major concern to stake holders in education and to everyone as a whole. If a nation's educational system is functional, it means that the economic, social and political developments of such country is achieved already. It is also shown on the employability of the citizenry. In Nigeria and in Rivers state specifically, a lot of youths are out there roaming the street without employment, thus taking the minds of people back to the type of education that is given to the people. If the nation has a functional education, why do we have the problem of unemployment? What are those factors that help achieve a functional secondary education? Is availability of resources not one of the strongest factors in enhancing a functional education? If yes, what level of the availability of these resources can be found in our secondary schools in Rivers state, Nigeria? The level of available resources in a school determines the level of functional activities in such a school. On the premise that there is a strong relationship between resource availability and achievement of functional education, is the researcher bothered to investigate the extent of availability of resources in schools that can enhance in managing functional secondary education in Rivers state, Nigeria.

\section{Aim And ObJectives OF The Study}

The aim of the study is to investigate the imperative for the availability of resources and the level of availability of such resources for managing functional secondary education for sustainable development in Rivers state, Nigeria. Specifically the objectives are to;

1. Find out the ways material resources would enhance functional secondary education for sustainable development in Rivers state, Nigeria.

2. Find out the level of availability of resources for managing functional secondary education for sustainable development in Rivers state, Nigeria. 
Imperative for the Availability of Resources for Managing Secondary Functional Education in Rivers State, Nigeria

\section{Research questions}

The following research questions guided the study;

1. In what ways would material resources enhance functional secondary education for sustainable development in Rivers state, Nigeria?

2. What is the level of availability of resources for managing functional secondary education for sustainable development in Rivers state, Nigeria?

\section{Methodology}

The study adopted a descriptive survey design and the population comprised all the 247 secondary schools with a total 247 principals and 247 vice principals making a total of 494 who served as the respondents. Stratified random sampling technique was used to draw 64 principals and 64 vice principals making a total of 128 being the sample size which is $25 \%$ of the total respondents. Questionnaire tagged "Availability of Resources for Managing Functional Education Questionnaire" (ARMAFEQ) was the instrument used for data collection developed by the researcher. The instrument comprised two sections A \& B. Section A comprised demographic data while section B comprised the questionnaire items based on the variables of the study and was based on four points likert scale of SA (4 points), A (3 points), D ( 2 points) and SD (1 point). Mean and standard deviation were the statistical instruments used for data collection.

\section{RESUlT}

Research question1: In what ways would material resources enhance functional secondary education for sustainable development in Rivers state, Nigeria.

Table 1: Mean and standard deviation analysis of the opinion of principals on the ways facilities enhance functional secondary education in Rivers State, Nigeria.

\begin{tabular}{|l|l|l|l|l|}
\hline S/N & ITEMS & X & SD & DECISSION \\
\hline 1 & Promotes understanding of subject matter & 3.10 & 1.47 & Agreed \\
\hline 2 & Makes teaching and learning clearer & 3.18 & 1.80 & Agreed \\
\hline 3 & Improves skills and knowledge among students & 3.00 & 1.41 & Agreed \\
\hline 4 & Improves quality of teaching & 2.86 & 1.37 & Agreed \\
\hline 5 & Improves teachers effectiveness & 3.46 & 1.65 & Agreed \\
\hline 6 & Bridge the gap between teaching and learning & 3.29 & 1.61 & Agreed \\
\hline 7 & Helps students to participate fully in discussions & 3.08 & 1.46 & Agreed \\
\hline 8 & Makes teaching learner's centered & 3.45 & 1.65 & Agreed \\
\hline 9 & Facilitates the learning process & 3.58 & 1.80 & Agreed \\
\hline 10 & Helps teachers to communicate more effectively & 3.29 & 1.62 & Agreed \\
\hline 11 & Helps learners to assimilate more meaningfully & 3.00 & 1.52 & Agreed \\
\hline 12 & Helps students to make use of their five senses & 2.71 & 1.38 & Agreed \\
\hline 13 & Helps to captivate the attention of students & 2.86 & 1.37 & Agreed \\
\hline 14 & Helps to facilitates classroom activities & 3.08 & 1.46 & Agreed \\
\hline
\end{tabular}

Data analysis on table 1 shows the mean of the opinion of teachers on the ways facilities enhance functional secondary school in Rivers state in Nigeria. All the mean scores for all items are greater than the criterion mean 2.50. This shows that the respondents agreed that facilities enhance functional secondary education in the following ways; promotes understanding of subject matter, makes teaching and learning clearer, improves skills and knowledge among students, improves quality of teaching, improves teachers effectiveness, bridge the gap between teaching and learning, helps students to participate fully in discussions, helps students to participate fully in discussions, makes teaching learner's centered, facilitates the learning process, helps teachers to communicate more effectively, helps learners to assimilate more meaningfully, helps students to make use of their five senses, helps to captivate the attention of students, and helps to facilitate classroom activities.

\section{Research question 2:}

What is the level of availability of resources for managing functional secondary education for sustainable development in Rivers state, Nigeria? 
Imperative for the Availability of Resources for Managing Secondary Functional Education in Rivers State, Nigeria

Table2. Mean and standard deviation analysis of opinion of respondents on the level of availability of resources for managing functional secondary education for sustainable development in Rivers state, Nigeria.

\begin{tabular}{|l|l|l|l|l|}
\hline S/N & ITEMS & X & SD & DECCISION \\
\hline 1. & School building & 3.00 & 1.52 & High \\
\hline 2 & Classrooms & 2.71 & 1.38 & High \\
\hline 3. & Instructional materials & 2.23 & 1.17 & Low \\
\hline 4. & Classroom furniture & 2.58 & 1.19 & Low \\
\hline 5. & Library facilities & 1.77 & 1.54 & Low \\
\hline 6 & Science laboratory equipment & 1.77 & 1.11 & Low \\
\hline 7. & Textbooks & 1.94 & 1.39 & Low \\
\hline 8 & Graphic materials & 2.31 & 1.32 & Low \\
\hline 9. & Audio visual materials & 1.05 & 0.89 & Low \\
\hline 10 & Computer & 1.38 & 1.19 & Low \\
\hline 11 & Sports equipment & 2.23 & 1.34 & Low \\
\hline 12 & Play ground & 3.45 & 1.65 & High \\
\hline 13 & Seats & 2.31 & 1.19 & Low \\
\hline 14 & School halls & 3.29 & 1.62 & High \\
\hline & Aggregate Mean & $\mathbf{2 . 1 6}$ & & Low \\
\hline
\end{tabular}

Data analysis on table 2 shows the mean of the opinion of teachers on the level of available resources for enhancing functional secondary education in Rivers state, Nigeria. Items 1, 2, 12 and 14 have mean scores above the criterion mean of 2.50 which shows that the respondents agreed those items such as School building, Classrooms, Play ground; School halls are highly available in schools. Other items have mean scores below the criterion mean which shows that the level of availability of those items such as Instructional materials, Library facilities, Science laboratory equipment, Textbooks, Graphic materials, Audio visual materials, Computer, Sports equipment and Seats is low. is low.

The aggregate mean scores of 2.16 shows that availability of resources in schools in Rivers state, Nigeria is low generally.

\section{DisCUSSIONS OF FINDINGS}

The finding in table one revealed that resources enhance functional basic education in the following ways; promotes understanding of subject matter, makes teaching and learning clearer, improves skills and knowledge among students, improves quality of teaching, improves teachers effectiveness, bridge the gap between teaching and learning, helps students to participate fully in discussions, helps students to participate fully in discussions, makes teaching learner's centered, facilitates the learning process, helps teachers to communicate more effectively, helps learners to assimilate more meaningfully, helps students to make use of their five senses, helps to captivate the attention of students, helps to facilitates classroom activities. The finding agrees with the findings of Ogbonnaya (2011) who points out that availability of resources in schools is an ingredient for good academic achievement. According to him infrastructural and learning facilities constitute factor resources for the achievement and execution of educational programmes. It also agrees with Nwafor in Igbozuruike, Ebunu \& Onu (2017) notes that capital physical equipment such as classrooms, libraries, laboratories, workshops for the various technical and science subjects, audio visual facilities etc, are critical for enhancing comprehension and retention. The implication of this finding is that when students achieve academically it means there is effective teaching and learning existing in schools. Effective teaching can be achieved when the facilities are available to enhance teaching and learning process.

The findings also revealed the level of availability of resources in schools. From the findings materials such as, School building, Classrooms, Play ground, School halls are highly available in schools while the level of availability of facilities such as Instructional materials, Library facilities, Science laboratory equipment, Textbooks, Graphic materials, Audio visual materials, Computer, Sports equipment and Seats is low. This finding agrees with Abolo and Victor-Orivoh(2017) who did a work on the availability of resources in schools; also found out that $81 \%$ of teachers were of the opinion that material resources for the implementation of the UBE programme in schools in Isoko LGA in Nigeria is inadequate. The finding is also in agreement with Ogbonnaya (2011:26-27) who remarks that; Obstacle to quality assurance in institutions is poor infrastructural and learning facilities. The quantity, quality and standard of infrastructural and learning facilities has impact on the quality of 
students produced in our tertiary institutions. For instance, where laboratory equipment and chemicals are inadequate, science education programmes will be hindered. Also the inadequacy of library books, computer equipment and accessories, classroom and office space for lecturers will seriously affect the quality of educational programmes.

\section{CONCLUSiON}

From the findings of the study the following conclusions were dawn. The use of resources in schools is of immense benefit to achieve a functional education for a functional society but the level of availability of these resources is low. This implies that achieving a functional education in the face of poor availability of resources is a mirage and something needs to be done.

\section{RECOMMENDATIONS}

To make available resources in secondary schools to manage functional secondary education in Rivers state, Nigeria, the following recommendations are made;

1. All stake holders in education both local (parents and community leaders) and international should be involved in the provision of material resources in schools through donations and contributions.

2. Until the government rises above the politics of neglecting the education sector, development in education will continue to be dwindling. The government therefore should adequately fund the educational sector so that material resources in secondary schools will be adequately provided to enhance functionality of education.

3. Non-governmental organizations and philanthropists should help in providing some of the resources within the level of their affordability so that effective management of functional secondary education can be achieved.

4. School managers and teachers should learn to and have the practice of resource management in terms of maintenance of resources to keep in order the already existing ones.

\section{REFERENCES}

[1] Abolo E. V. \& Victor-Orivoh A. F. (2017). The perception of parents and school management on universal basic education programme in an of recession in Isoko south local government area, Delta. African Journal of Educational Research and Development (AJERD). 9 (3) 265-274

[2] Amadioha, S. W. (2013). Assuring the quality of inputs in university education in Nigeria. African Journal of Higher Education studies and development (AJHESD). 2 (119-126)

[3] Federal Republic of Nigeria (2013). National policy on education. Lagos: Nigerian Educational Research and development Council.

[4] Igbozuruike, I. U., Ebunu, A. A. \& Onu, A. I. (2017). Effective management of secondary education goals and declining economy of Rivers state. African Journal of Educational Research and Development (AJERD). 9 (3) 205-219

[5] Igbudu J. N. \& Ipalibo-Wokoma, B. (2017). Managing secondary education in an era of economic recession in Nigeria. African Journal of Educational Research and Development (AJERD) 9 (1) 141-151

[6] Ogbonnaya, N. O. (2011). Quality assurance in tertiary institutions. African Journal of Educational Research and Development (AJERD). 4 (2) 22-29

[7] Osaat, D. S. (2011). Functional education in Nigeria: issues, problems and way forward. In S. D. Osaat (ed). Education in Africa. The $21^{\text {st }}$ century experience. Port Harcourt: University of Port Harcourt Press

[8] Okeke, B. S. (2007).Politics of education: The Nigerian experience. Awka: Doone Printing and Publishing.

[9] Ojokheta, K. O. \&Omoregie, C. O. (2008). A critique of formal educational system as an instrument for sustainable development. In M. Boncarvalas \& R. Aderinoye (eds). Education for millennium development: Essays in honour of Prof. Michael Omolewa 1 (82-92).

Citation: Osaat, Dinah Sunday. "Imperative for the Availability of Resources for Managing Secondary Functional Education in Rivers State, Nigeria "International Journal of Humanities Social Sciences and Education (IJHSSE), vol 4, no. 12, 2017, pp. 78-82. doi: http://dx.doi.org/10.20431/2349-0381.0412010.

Copyright: (c) 2017 Authors. This is an open-access article distributed under the terms of the Creative Commons Attribution License, which permits unrestricted use, distribution, and reproduction in any medium, provided the original author and source are credited. 